Notre Dame Law School

NDLScholarship

Journal Articles

Publications

1997

\title{
Non-Representational Jurisprudence: A Centennial Reading of "The Path of the Law"
}

Robert E. Rodes

Notre Dame Law School, robert.e.rodes.1@nd.edu

Follow this and additional works at: https://scholarship.law.nd.edu/law_faculty_scholarship

Part of the Jurisprudence Commons, and the Legal History Commons

\section{Recommended Citation}

Robert E. Rodes, Non-Representational Jurisprudence: A Centennial Reading of "The Path of the Law", 42 Am. J. Juris. 263 (1997). Available at: https://scholarship.law.nd.edu/law_faculty_scholarship/859

This Article is brought to you for free and open access by the Publications at NDLScholarship. It has been accepted for inclusion in Journal Articles by an authorized administrator of NDLScholarship. For more information, please contact lawdr@nd.edu. 


\title{
NON-REPRESENTATIONAL JURISPRUDENCE: A CENTENNIAL READING OF "THE PATH OF THE LAW"
}

\author{
ROBERT E. RODES, JR.
}

The prophecies of what the courts will do in fact ... are what I mean by the law.

The law can ask no better justification than the deepest instincts of man. Therefore, the prophecies of what the courts will do in fact can ask no better justification than the deepest instincts of man.

On January 8, 1897, Oliver Wendell Holmes, then a justice of the Supreme Judicial Court of Massachusetts, delivered an address at the dedication of the new hall of the Boston University School of Law. His speech was published in volume 10 of the Harvard Law Review under the title "The Path of the Law." It is generally regarded as the foundation stone of the American Legal Realist movement-a movement which in the next generation or two was to enlist virtually the entire legal profession of the United States, and in later generations was to provide at least a starting point for even its severest critics.

Mary Ann Glendon has suggested that Holmes did for the law what some of his contempories did for the arts:

Holmes was a Picasso-like figure-larger than life, boldly iconoclastic, yet mindful of his lineage and of the continuity of legal culture. "The Path of the Law" was his Demoiselles of Avignon.'

The comparison is not vitiated by the observation that Picasso tends to show noses in profile, eyes in full face, and furniture from above. Holmes too shifts perspective with elegant insouciance. Also like Picasso, he presents exaggerated and distorted pictures of the realities he addresses. But there is a major difference. People are in no danger of thinking that women really look like Picasso's Demoiselles, while they are in real danger of thinking that the law is really like Holmes's description in "The Path of the Law."

My object in the following critique is not to make light of either "The Path of the Law" or its author. I am an American lawyer of my generation. I cut my academic teeth on this essay. I went to class under what seemed a more than life-size portrait of Holmes, and one of my favorite teachers

1. Mary Ann Glendon, A Nation Under Lawyers (1994), p. 191. 
was his law clerk and biographer, Mark deWolfe Howe. Furthermore, his intellectual categories, whether or not acknowledged, were and are everywhere in American law. I can no more avoid being a follower of Holmes than Molière's Bourgeois Gentilhomme could avoid speaking in prose. Holmes is at least as important in law as Picasso in painting. All I want to show here is that, like Picasso, he is not representational.

For this purpose, I will comment on particular passages in the order they appear in the essay, and show that they are not consistent with the legal enterprise as we actually know it, and often not consistent with each other. The page references after the different passages are to volume $\mathbf{1 0}$ of the Harvard Law Review.

\section{1. "The object of our study, then, is prediction, the prediction of the incidence of the public force through the instrumentality of the courts." (p. 457)}

This claim raises two questions. First, is the prediction referred to in fact the object of the study of law, and, second, is the study of law the best way to come at that prediction? Neither question admits of an unqualified affirmative. Much of the study of law is addressed to transactional lawyering, and good transactional lawyering involves not predicting the courts but keeping away from them. Granted, one way to keep from the courts is for everyone to know what will happen to a case when it goes there. But a much better way is for transactions to be set up so clearly and fairly that misunderstandings are prevented, and no one has a grievance to litigate over. In many law school classes, when we study a case, we are less interested in how the next one will come out than in how this one could have been prevented.

But if we should want to find out what the courts will do next, it is not always the person most learned in the law who is most apt to know. There are whole levels of courts that politicians, bill collectors, caseworkers, landlords, policemen, and newspaper reporters understand better than the lawyers who practice in them, let alone the rest of the bar. At other levels there are people who make their living as jury consultants, predicting what kind of jurors will be most apt to vote for what kind of litigants. In the field of personal injury, firms with suitable data bases make predictions that lawyers will pay for, and insurance claims adjusters with neither data bases nor law degrees make predictions that are probably as good. 
2. “. . a lawyer's statement of the case, eliminating as it does all the dramatic elements with which his client's story has clothed it, and retaining only the facts of legal import. ..." (p. 458)

Holmes goes on to explain that the lawyer eliminates the dramatic elements because he foresees that those elements will make no difference in the application of the public force. With the examples he uses-notably that of the hat wom by one of the parties to a contract - he is probably right. But with many dramatic elements he is quite mistaken. Ask any trial lawyer how a particularly vivid color photograph of a mangled corpse will affect a murder case or a wrongful death case. We keep such things out of our trials not because we predict that they will not affect the outcome, but because we predict that they will and we do not want them to.

3. “... a legal duty so called is nothing but a prediction that if a man does or omits certain things he will be made to suffer in this or that way by judgment of the court." (p. 458)

If this is in fact the case, interesting consequences follow. The most important is that $I$ have no legal duty to do anything I can get away with not doing, or not to do anything I can get away with doing. It can be argued, I suppose, that the legal duty I used to think I had can be no great loss if the law has no way of enforcing it. The moral duty, if there is one, has not gone away, and in the absence of legal enforcement, my willingness to live up to my moral duties is all that would stand in the way of my violating the legal duty if there were one.

This reasoning disregards the moral obligation to obey the law. If, as St. Thomas Aquinas puts it, a just law is binding in conscience, ${ }^{2}$ then it would seem that a legal duty might create a moral duty even if its breach had no court-imposed consequences. Here is an example. Some years ago, the constitution and laws of Indiana contained provisions forbidding all forms of gambling. ${ }^{3}$ Nevertheless, my university had an annual Mardi Gras celebration with roulette wheels and the like, and several Catholic parishes ran bingo games. Neither the police nor the prosecutor interfered in any way with these games, and, given the mores and the politics of the community, it could be confidently predicted that they would not do so in the future. But when a new bishop took office, he stopped all gambling under church auspices-not because he considered it immoral, but because it was against the law. Under the language quoted here, it would seem that the bishop was mistaken.

2. Summa Theologiae, I, II, Q. 95, art. 5.

3. Indiana Constitution, Article 15, Section 8, repealed in 1988. 
Another consequence of this language is harder to pin down. It has to do with the reference to suffering "in this or that way." If these words are to be taken literally, the consequences of violating any legal duty are built into the definition of the duty, so that it is impossible to attach new consequences without redefining the duty. Here is a hypothetical I use in class to illustrate this point: a civil rights act has just been enacted, which makes it an "unfair discriminatory practice" for a real estate broker to refuse to show or sell a house on account of the race of the potential purchaser. The act provides for enforcement through an administrative cease and desist order, which a court on application will turn into a mandatory injunction. May the licensing authorities suspend the license of a broker who violates this act? If the statement that he has a duty not to discriminate is identical in meaning to the statement that if he discriminates he will be subject to the enforcement procedures in the act, then the licensing authorities are usurping the function of the legislature if they visit other sanctions on his discriminatory practices. Whether we wish to limit the licensing authorities in this way depends on our views of administrative law and civil rights. It seems inappropriate to define legal duties in such a way as to foreclose the question.

\section{$\pitchfork *$}

4. "The law is the witness and external deposit of our moral life. Its history is the history of the moral development of the race. The practice of it, in spite of popular jests, tends to make good citizens and good men. When I emphasize the difference between law and morals I do so with reference to a single end, that of learning and understanding the law." (p. 459)

If, as Holmes seems to admit here, the law embodies moral judgments, how can moral discernment and moral argumentation not be relevant to predicting what the courts will do? If by "the difference between law and morals" Holmes means the exclusion of moral reflection from legal analysis-and various passages in the essay suggest that he does mean that - this passage would seem to be self-contradictory.

5. "If you want to know the law and nothing else, you must look at It as a bad man, who cares only for the material consequences which such knowledge enables him to predict, not as a good one, who finds his reasons for conduct, whether inside the law or outside of it, in the vaguer sanctions of conscience." (p. 459)

Here again, Holmes overlooks the moral obligation to obey the law. While, as Holmes points out earlier on this page, a "bad man has as much reason as a good one for wishing to avoid an encounter with the public force," it is not true that a bad man has as much reason as a good one for wishing to obey the law. As a general matter, good people would like to be 
law-abiding citizens. To that end, they need their legal advisers to help them discern what the law requires, and relate these requirements to other claims on their consciences. Lawyers who are not equipped to do that do not understand their profession well enough to practice it.

In fact, good people, when they enter into legal transactions or when they resolve disputes, combine moral and legal considerations in a great variety of ways. Their lawyers must be prepared to follow them-and sometimes lead them-through whatever combination may be required in a given case. The literature of legal counseling is full of examples. ${ }^{4} \mathrm{~A}$ testator wants to know whether to tell his wife about the illegitimate child he fathered before he met her. The parents of a young family want to know what to do about a proposal to turn a neighboring mansion into a home for mentally disabled adults. A member of a family business thinks he has been overreached by his relatives. An understanding of the law is essential in resolving these problems, and a bad man's understanding will not do.

6. "The duty to keep a contract at common law means a prediction that you must pay damages if you do not keep it-and nothing else. If you commit a tort, you are liable to pay a compensatory sum. If you commit a contract, you are liable to pay a compensatory sum unless the promised event comes to pass, and that is all the difference." (p. 462)

This relates to a point I made a little earlier: Holmes has defined legal duties in such a way that the sanction for breach of any duty is built into the definition of the duty itself. As a result, he has to regard the sanction as an alternative way of complying with the legal duty rather than a consequence of not complying with it. "The law requires $x$ on penalty of $y$," is simply another way of saying that the law offers a choice between $x$ and $y$. The above quotation is the centerpiece of a substantial passage in which Holmes develops this option. He begins (p. 461) by showing that there is no significant difference between a tax and a fine: both are money payments exacted of those who choose to do particular things. He goes on to show that on the proper understanding of a contract, the parties have the option of performing or paying damages.

To be consistent, he would have to say that committing a tort and paying damages is an acceptable alternative to not committing the tort. It appears that recently some major manufacturers have in fact calculated their options in just this way. But when discovery has brought up evidence of such a

4. The first of the following examples comes from Professor Teresa S. Collett. The others are from Thomas L. Shaffer and Robert F. Cochran, Jr., Lawyers, Clients and Moral Responsibility (1994). 
calculation, the courts have responded by imposing punitive damages. 5 Punitive damages are based on the willfulness of the defendant's conduct and the ability of the defendant to pay. Their object is to keep committing the tort and paying the damages from being a viable option for potential tortfeasors. Presumably, the reason the courts wish to keep the tort from being a viable option is that they already know it is not a legal one.

Punitive damages for breach of contract are rare-though not unknown. ${ }^{6}$ But where a breach of contract can be characterized as "willful"-as would be the case if a party took seriously Holmes's offer of an option not to perform-damages are often awarded for the mental distress caused by the breach. ${ }^{7}$ Such damages are predicated on an understanding that the person against whom they are awarded has done something wrong.

All this of course is to say nothing of what it would do to a person's reputation in the business community for everyone to understand that he or she felt free to make contracts and then pay damages instead of living up to them. Holmes might respond that such a person's bad reputation would rest on a moral, not a legal, judgment regarding his or her behavior. But I think the moral judgment would rest on a perception of what the law required. A good faith disagreement over what you have promised to do will not affect your reputation in the same way as a pronouncement that you regard keeping your promises as optional.

\section{7. "It is enough to take malice as it is used in the law of civil liability for wrongs ... to show that it means something different in law from what it means in morals ...." (p. 463)}

To make his point, Holmes describes an Elizabethan slander case involving a preacher who told from the pulpit a story out of Fox's Book of Martyrs. Although the story was both false and discreditable to the plaintiff, the court said the preacher was not liable because he had meant no harm and therefore had no malice. ${ }^{8}$ Holmes says that the rule of that case has since been discredited. He refers in a footnote to a dissenting opinion of his own in a Massachusetts case where the majority found a newspaper publisher not liable for inadvertently naming the wrong man in an account of a police court proceeding. ${ }^{9}$

Holmes regards the preacher's case, and no doubt the prevailing opinion in the newspaper case, as examples of an unfortunate failure to distinguish

5. Restatement (Second) of Torts $\$ 908 ;$ W. Page Keeton, Prosser and Keeton on the Law of Torts (5th ed. 1984), pp. 9-15.

6. Restatement (Second) of Contracts $\S 355$.

7. Ibid., \$353; "Damages," Corpus Juris Secundum \& 69.

8. Greenwood v. Prick, cited in Brook v. Montague, Cro. Jac. 90, 91, 79 Eng. Rep. 77, 78 (1605).

9. Hanson v. Globe Newspaper Co., 159 Mass. 293, 34 N.E. 462 (1893). 
malice as a moral failing from malice as a ground for liability in a defamation case. From the methodology he has laid down earlier in the essay, I do not understand how he can find fault with the way a court reasons, as long as his reading of its opinion will help him predict how it will reason next time. If the courts wish to conflate legal and moral malice, then the conflation of legal and moral malice will be the law.

Despite his failure to convince a majority of his colleagues on the Massachusetts court, Holmes was generally right about the evolution of the law of slander and libel from the Elizabethan period to his own. Also, given the course the evolution took, he was probably right that the continuing use of the word "malice" was unnecessarily confusing. On the other hand, he was quite wrong to imply, as he seems to, that moral considerations played no part in the evolution. The history is too complicated to take up here, but I think it accords pretty well with the growing recognition elsewhere in the law of torts that people ought to take responsibility for the natural consequences of what they do. The great transition case according to Prosser is Bromage v. Prosser ${ }^{10}$ (1825), in which the King's Bench likened the gratuitous undermining of people's reputations to the gratuitous maiming of their cattle or poisoning of their fish. If you do something obviously harmful for no good reason, you cannot be heard to say that you meant no harm. To me, this looks like a moral principle. I believe that the other cases that followed Bromage can be related to moral principles in the same way.

8. "Suppose a contract is executed in due form and in writing to deliver a lecture, mentioning no time. One of the parties thinks that the promise will be construed to mean at once, within a week. The other thinks that it means when he is ready. The court says that it means within a reasonable time." (p. 464)

Holmes takes this example as showing that the enforcement of contracts is based not on a meeting of minds, but on a consonance of formalities. But that is not in fact what it shows. Rather, it shows that if two parties sketch out an agreement with terms missing, the court will supply reasonable terms so the agreement will not fail. In deciding on reasonable terms, the court, on the basis of common understanding, decides what would be a fair-i.e., moral-way for either party to treat the other. Holmes has constructed his hypothetical in such a way that the expectations of the parties are both fatuous. They are therefore neither morally compelling nor legally binding. But that is no reason for saying that the requirement that the court establishes in their place is a mere formality, devoid of moral content.

10. 4 B. \& C. 247, 107 Eng. Rep. 1051; William L. Prosser, Prosser on Torts (1941), p. 815. 
9. "For my own part, I often doubt whether it would not be a gain if every word of moral significance could be banished from the law altogether, and other words substituted which should convey legal ideas uncolored by anything outside the law." (p. 464)

I believe I have shown that it would not be a gain: that it would seriously impair the intelligibility of the whole enterprise. Indeed, in the second part of the essay, which begins with the paragraph following this language, we shall see that Holmes himself cannot avoid words of moral significance when he turns from "the limits of the law" to "the forces which determine its content and its growth."

10. "Even if every decision required the sanction of an emperor with despotic power and a whimsical turn of mind, we should be interested none the less, still with a view to prediction, in discovering some order, some rational explanation, and some principle of growth for the rules which he laid down." (p. 465)

There is a certain amount of truth in this, but it is overstated. The emperor's whimsical turn of mind may (and probably did under a leader such as Idi Amin) reach the point where the predictive function can be exercised better by a psychiatrist than by a lawyer. While Holmes is right to say, as he is about to at this point, that mere logic is not adequate to support legal analysis, there has to be a certain colorable rationality in the material being analyzed if the analysis is to be called legal. I think there must be some kind of moral element as well. One can accept a good deal of what Holmes says about the distinction between law and morality, and still believe that if an exercise of power has no modicum of moral legitimacy, the work of analyzing it belongs to someone other than a lawyer."

11. "Behind the logical form lies a judgment as to the relative worth and importance of competing legislative grounds. . . " (p. 466)

"I think that the judges themselves have failed adequately to recognize their duty of weighing considerations of social advantage." (p. 467)

It seems to me obvious that a judgment as to the relative worth and importance of competing legislative grounds is a moral judgment, and

11. Cf. H.L.A. Hart, The Concept of Law (1961), pp. 18-25. 
considerations of social advantage are moral considerations. Furthermore, in referring to the duty of judges, Holmes must be thinking of a moral duty, for under his definition of law judges cannot have a legal duty unless other judges will make them carry it out. The inconsistency of this language with Holmes's earlier strictures on the exclusion of moral considerations from the law is evidently less striking to Holmes than it is to me. Perhaps the reason is that Holmes's understanding of morality is different from mine. I suppose that for a strict enough Kantian considerations of social advantage would be quite different from moral considerations, ${ }^{12}$ and perhaps Holmes is thinking in Kantian terms when he deals with morality. Still; at this point in his discussion; he is pretty far removed from his original enterprise of predicting what the courts will do.

12. "We think it desirable to prevent one man's property being misappropriated by another, and so we make larceny a crime." ( $p$. 469)

Property is a legal concept. "One man's property" consists of those objects that the law has assigned that man. But if we are to believe Holmes in the first part of this essay, the way the law assigns property to a man is by arranging to punish anybody who takes it away from him. It follows that Holmes cannot be right in saying that we make larceny a crime in order to prevent one man's property being misappropriated by another. Until we made larceny a crime, nobody had any property for anyone else to misappropriate.

13. "A slip corner is left open for thieves to contend, if indicted for larceny, that they should have been indicted for embezzlement, and if indicted for embezzlement, that they should have been indicted for larceny, and to escape on that ground." (p. 470)

From the "bad man" standpoint that Holmes has bidden us adopt, in what sense can a person who escapes punishment be a thief?

12. See Ivo Thomas, "The Growth of Legislative Morals," 19 Am J. Jur. (1974), p. 39. 
14. "I think that the law regards the infliction of temporal damage by a responsible person as actionable if, under the circumstances known to him the danger of the act is manifest according to common experience, or according to his own experience if it is more than common, except in cases where upon special grounds of policy the law refuses to protect the plaintiff or grants a privilege to the defendant." (p. 471)

This has to be a moral claim. The reason people are made to pay for the harm they do is that they should not have done it. And that they should have known it would be harmful seems a pretty good reason for saying they should not have done it. I would suppose that the "special grounds of policy" to which Holmes attributes the exceptions to his principle would also be established on the basis of some moral claim.

15. "If a man goes into law it pays to be a master of it, and to be a master of it means to look straight through all the dramatic incidents and to discern the true basis for prophecy. ... I I have in mind cases in which the highest courts seem to me to have floundered because they had no clear ideas on some of these themes." (p. 475)

This passage brings into particularly sharp focus the discrepancy between the two halves of the essay. The master of law is the one who can discern the true basis for prophecy. But the true basis for prophecy of what? For anyone who has read the essay up to this point, the answer has to be for prophecy of what the courts will do in fact. But in that case, how can the highest courts have floundered? A trial court or an intermediate appellate court can presumably flounder by failing to predict the decisions of a court to which its cases go on appeal. But a highest court can only flounder by failing to predict its own decisions. If Holmes's clear ideas on this or that theme are not shared by the highest courts he is concerned with, then, from the standpoint of prophecy on which he continues to insist, the courts are not floundering, Holmes is. 


\section{6. "The law can ask no better justification than the deepest instincts of man." (p. 477)}

Despite his professed opposition to natural law doctrine, Holmes offers a rich supply of proof texts supporting it. This is one of my two favorites. ${ }^{13}$ It is the culmination of a discussion of prescription in which Holmes says that the prevailing legal doctrine is based on a primordial human attitude toward something a person thinks is his own: "The connection is further back than the first recorded history. It is in the nature of man's mind." I gather that Holmes's understanding of philosophy kept him from connecting judgments of this kind with natural law, just as it kept him from connecting considerations of social advantage with morality. In his little essay on natural law, ${ }^{14}$ he distinguishes "Can't Helps" from " $a$ priori discernment" and seems to regard only the latter as natural law doctrine. For Holmes, then, one can fight and die for one's intuitions about human nature, ${ }^{15}$ but one cannot philosophize about them.

I disagree with him strongly about the role of intuition in philosophy, but I do not want to discuss that disagreement here. Rather, I want to suggest that the language quoted here makes Holmes's philosophical rejection of natural law inconsistent with the meaning of law as he established it at the beginning of his essay. If law is a prediction of what the courts will do, and if reflection on human nature will help us to make such a prediction, then there is such a thing as natural law, regardless of its place in the philosophical firmament. Holmes's failure to recognize that this is the case is, I believe, a final example of his failure to make the two halves of his essay consistent with one another.

The question of what to make of this essay has of course engaged the attention of many people. Among the most recent are nine scholars whose comments are appended to a republication of the essay itself in the March, 1997 issue of the Harvard Law Review. ${ }^{16}$ Four of them draw on a combination of psychology and intellectual history. ${ }^{17}$ On the one hand, Holmes admired the industrial progress of the Gilded Age, the men who made it

13. The other is: "The law has grown, and even if historical mistakes have contributed to its growth it has tended in the direction of rules consistent with human nature." Brown $v$. United States, 256 U.S. 335. 343 (1921).

14. 32 Harv. L. Rev. (1918), p. 40.

15. See "The Soldier's Faith" (1895) in Speeches (1913), p. 56.

16. 110 Harv. L. Rev. (1997), p. 991.

17. William W. Fisher III, "Interpreting Holmes," ibid., p. 1010; Robert W. Gordon, "The Path of the Lawyer," ibid., p. 1013; Richard D. Parker, "The Mind of Darkness," ibid., p. 1033; G. Edward White, "Investing in Holmes at the Millennium," ibid., p. 1049. The reference to social Darwinism is Fisher's, that to the friendship with Henry Adams is Gordon's. 
happen, and the lawyers who served them: there were even hints of social Darwinism in his attitude. On the other hand, he was a friend of Henry Adams, and showed on occasion the same wistful, fin de siècle skepticism, the same dim longing for an unattainable and probably nonexistent transcendence.

Two commentators make Holmes a predecessor of postmodern deconstruction. ${ }^{18}$ By demolishing the presuppositions that supported the legal analysis of his time, Holmes made it possible for later generations to apply political, social, economic, or even moral analysis to legal questions as they arose.

The remaining three stress Holmes's preoccupation with science. ${ }^{19}$ Like many of his contemporaries, he defined the rational on the model of the natural sciences. His object, therefore, was to sweep away the metaphysical and obscurantist traditions of less enlightened times, and so clear the way for a rational jurisprudence modelled on the natural sciences.

These different views all seem to focus mainly on what the authors believe Holmes thought rather than on what he says here, and to reconstruct his thought largely from evidence unrelated to this particular essay. Furthermore, they all seem to belie the first sentence of the essay: "When we study law we are not studying a mystery but a well known profession." Returning to the Picasso analogy, they seem to be making the essay representational by having it represent something other than what it claims to represent, which is law. Indeed, Judge Posner, one of the third category of commentators as I have described them, says firmly that, "in Holmes's view as articulated or implied in The Path of the Law, what judges do is not law in any sense that the legal profession will recognize." ${ }^{20}$ Posner is more upfront about it than the others are, but I think they are all preserving either the philosophical or the psychological coherence of the essay by downplaying the simplicity of its reference to "the legal profession."

The article "Cubism" in the Encyclopedia Americana says this about Picasso:

Perspective painting had insisted on a single, unified point of view: what would be observed by a spectator standing in a fixed position before the subject. In Les Demoiselles. . . , Picasso shifted the point of view at will. ${ }^{21}$

18. Tracy E. Higgins, "Straying from the Path," ibid., p. 1019; Martha Minow, "The Path as Prologue," ibid., p. 1023.

19. Sheldon M. Novick, "Holmes's Path, Holmes's Goal," ibid., p. 1028; Richard A. Posner, "The Path Away from the Law," ibid., p. 1039; David Rosenberg, "The Path not Taken," ibid., p. 1044.

20. Ibid., p. 1041.

21. H.H. Amason, "Cubism," 8 Ency. Amer. (1986), p. 307. 
I believe something of this kind is going on here. Classical jurisprudence, like perspective painting, insisted on a single, unified point of view. Whether you study law from Blackstone's Commentaries or Langdell's casebooks, it is a system of rules: do this, don't do that, and your position is that of a detached observer scrutinizing the rules in some orderly fashion. But Holmes, like Picasso, shifts the point of view at will. He invites you at different places in his essay to be student, professor, bad man, lawyer, judge, social scientist, historian, philosopher, and even mystic, and to ask from each standpoint, "What if this happens?" and "What shall I do about that?"

Whatever the metaphysical or epistemological objections to Holmes's shifting viewpoints, "The Path of the Law" has taught important lessons that lawyers of later generations are not apt to forget. The most important is that people go to lawyers for help with their practical concerns. It is a good thing for lawyers to know that, and a good thing for law schools to teach them. For the purpose, they must learn not to rest on the conceptual elegance of their analysis of legal questions, and not to conflate law and morality. There is an important place for both conceptual and moral analysis in dealing with a typical legal problem, but we must be careful in the process not to forget what the problem is.

Also, law has power behind it. Therefore, legal questions are never mere questions of how people ought to behave: they are always questions about how power can and should be deployed. By deploying power we make things happen, both in this or that case and in society generally. Some of the things we make happen will be good and others will not be. Therefore, it behooves us when we deal with a legal question to figure out what will happen if we decide it in this way or that, and whether we want that to happen.

What is important about these lessons is that they have always been major concerns of lawyers, legislators, and judges, whereas the prevailing jurisprudence of Holmes's time tended to neglect them. In "The Path of the Law," Holmes brought them all to our attention in an elegant, indeed, unforgettable package. But he did not tell us how to organize them coherently. On that we are still at work. 
